\title{
Skrivaju li se banke u sjeni i u Hrvatskoj?
}

\section{Mirna Dumičić* \\ Tomislav Ridzak**}

ZNANSTVENI ČLANAK

DOI: https://doi.org/10.15179/pkiep.27.2.1

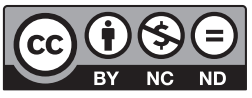

\section{Sažetak}

Ciljevi su ovog rada objasniti pojam bankarstva u sjeni i razloge zbog kojih je iz perspektive financijske stabilnosti važno steći spoznaje o subjektima ili aktivnostima koji se mogu opisati na taj način. U tom kontekstu provedena je analiza domaćeg financijskog sustava i poslovnih praksi kako bi se ocijenila važnost banaka u sjeni u Hrvatskoj i identificirali mogući sistemski rizici iz tog izvora. Rezultati analize pokazuju da visina udjela nebankovnih financijskih institucija te ročna struktura njihovih obveza i potraživanja u ovom trenutku nisu rizik koji bi mogao ugroziti financijsku stabilnost, dok se među najrizičnijim institucijama izdvajaju "ostali financijski posrednici" koji uključuju faktoring društva i društva za lizing.

Ključne riječi: banke u sjeni, bankarski sektor, nebankovne financijske institucije, makroprudencijalna politika, financijska stabilnost, sistemski rizici, Hrvatska

JEL klasifikacija: E51, F34, G01, G21, G23

\footnotetext{
^ Mirna Dumičić, Hrvatska narodna banka,e-mail: mdumicic@gmail.com.

** Tomislav Ridzak, Hrvatska agencija za nadzor financijskih usluga, e-mail: tomislav.ridzak@hanfa.hr.
} 
Jedan od preduvjeta uspješnog očuvanja financijske stabilnosti jest pravodobna identifikacija sistemskih rizika, neovisno o tome u kojem su se segmentu financijskog sustava pojavili. Recentna financijska kriza ukazala je na brojne propuste u nadzoru i regulativi bankarskog sektora, ali je razotkrila i sistemske rizike u dijelu financijskog sustava koji je bio djelomično ili potpuno izvan dosega regulative, a koji je zbog svoje veličine i međusobnih veza među financijskim institucijama znatno pridonio brzini širenja i visini troškova krizne epizode. To je posebice bilo izraženo u zemljama s razvijenim financijskim sustavima, premda su i u Hrvatskoj zabilježene aktivnosti koje spadaju u kategoriju regulatorne arbitraže i koje su rezultirale povećanim sistemskim rizicima unutar financijskog sustava. Stoga je i na međunarodnoj i na nacionalnoj razini prepoznata potreba da se, nakon uspostave makroprudencijalnog okvira za banke, počne izgrađivati institucionalni i regulatorni okvir za usporedivi nadzor nebankovnih financijskih institucija.

Za kvalitetnu raspravu o mogućnostima bolje makroprudencijalne regulacije bankarstva u sjeni nužno je razumjeti osnovna obilježja takve vrste poslovanja te na temelju dostupnih, ali još relativno oskudnih podataka pokušati procijeniti veličinu tog segmenta financijskog sustava i ocijeniti njegovu sistemsku važnost. Osnovni ciljevi ovog rada stoga su objasniti što se podrazumijeva pod pojmom bankarstvo u sjeni i zašto je iz perspektive financijske stabilnosti važno pokušati steći uvid u subjekte ili aktivnosti koji se mogu na taj način opisati. Usto, kako bi se ocijenila važnost banaka u sjeni u Hrvatskoj, provedena je preliminarna analiza financijskog sustava i poslovnih praksi koje se mogu okarakterizirati kao djelovanje banaka u sjeni, odnosno koje su povezane s izbjegavanjem regulative i premještanjem poslovanja iz jednog segmenta financijskog sustava u drugi, ročnim neusklađenostima koje bi mogle rezultirati prelijevanjem krize iz jednog segmenta financijskog sustava u drugi u slučaju nastupanja nekog stresnog događaja te izloženostima banaka prema

\footnotetext{
${ }^{1}$ Stavovi izneseni u ovom radu stavovi su autora i ne izražavaju nužno stavove Hrvatske narodne banke i Hrvatske agencije za nadzor financijskih usluga.
} 
nebankovnim financijskim institucijama. Poseban je naglasak stavljen na izloženost nebankovnih financijskih institucija prema sektoru države te njihovo oslanjanje na inozemne izvore financiranja. Analiza je provedena na temelju financijskih računa, podataka s novčanog tržišta te iskustava s procesom regulatorne arbitraže od strane financijskih institucija.

Rad je podijeljen na pet osnovnih dijelova. Nakon uvoda objašnjeno je što su to banke u sjeni, koje se institucije ili vrste aktivnosti najčešće tako opisuju te su izdvojeni problemi analize tog segmenta financijskog sustava. U trećem dijelu opisano je bankarstvo u sjeni u Hrvatskoj, a u posljednjem dijelu sažeti su glavni zaključci o važnosti makroprudencijalne regulacije svih segmenata financijskog sustava te o potencijalnim sistemskim rizicima povezanima s aktivnostima banaka u sjeni u Hrvatskoj.

\section{2. Što je bankarstvo u sjeni?}

Pojam bankarstvo u sjeni u upotrebu je uveo visoki dužnosnik PIMCO-a (Pacific Investment Management Company) Paul McCulley 2007. godine, kada se u govoru na godišnjem financijskom skupu u Jackson Holeu osvrnuo na nebankovne financijske institucije koje se bave ročnom transformacijom, odnosno kreiranjem dugoročnih plasmana iz izvora koji su kraćeg roka dospijeća, a izvan su dosega regulative koja se primjenjuje na kreditne institucije (Kodres, 2013). Pritom je istaknuto da su takvi pravno i financijski složeni subjekti u pravilu bili povezani s bankama, koje su na taj način prebacivale dio poslovanja izvan svojih bilanci (Economist, 2014).

Pregledom literature moguće je identificirati nekoliko glavnih obilježja aktivnosti koje se u literaturi opisuju kao bankarstvo u sjeni (Europska komisija, 2012; Jackson i Matilainen, 2012; Kodres, 2013; Europska komisija, 2013):

- ročna transformacija - kratkoročnim zaduživanjem financiraju se dugoročna ulaganja 
- transformacija likvidnosti - visokolikvidnim obvezama financiraju se manje likvidni oblici imovine

- izravno ili neizravno korištenje financijske poluge - za financiranje ulaganja rabe se posuđena sredstva

- transfer kreditnog rizika - rizik da dužnik neće moći podmiriti svoje obveze prebacuje se od zajmodavca na treću stranu

- prikupljanje sredstava u formi sličnoj depozitima

- prikupljanje sredstava u procesu sekuritizacije, posuđivanjem vrijednosnih papira i repo poslovima.

U praksi se pod bankama u sjeni najčešće podrazumijevaju subjekti uključeni u proces sekuritizacije, investicijski fondovi ili financijski posrednici poput društava za lizing koji odobravaju kredite ili se u svom poslovanju intenzivno koriste financijskom polugom poput fondova za omeđivanje rizika (hedge funds), otvorenih investicijskih fondova $\mathrm{s}$ privatnom ponudom i financijskih subjekata koji odobravaju kredite ili kreditne garancije, osiguravajuća i reosiguravajuća društva koja daju kredite ili kreditne garancije te društva za faktoring koja mogu služiti za izbjegavanje ograničenja velikih izloženosti koja vrijede za druge financijske institucije (Europska komisija, 2012, 2013).

Većinu europskih zemalja karakteriziraju bankocentrični financijski sustavi, u kojima banke imaju vodeću ulogu u mobilizaciji štednje, alokaciji kapitala i upravljanju rizicima. Nasuprot tome, u sustavima u kojima se znatan dio financiranja odvija putem tržišta kapitala naglasak je na financijskim tržištima i nebankovnim financijskim posrednicima. Pritom ne postoji jedinstveno stajalište o tome koji sustav povolinije djeluje na financijski i gospodarski razvoj iako se općenito smatra da su sustavi bazirani na većoj ulozi tržišta kapitala robusniji u krizama, pružaju veći izbor te smanjuju troškove financiranja (Europska komisija, 2018). U bankocentričnim sustavima problemi banaka mogu rezultirati nedostatnim financiranjem gospodarstva jer ne postoje dovoljno razvijeni alternativni izvori financiranja, dok s druge strane razvijena mreža financijskih posrednika istodobno povećava mogućnost regulatorne arbitraže. 
Poslovanje i postojanje banaka u sjeni motivirano je u prvom redu profitnim očekivanjima, premda u nekim slučajevima potreba za razvojem takvih institucija dolazi i iz smjera potražnje. Naime, svaka regulacija je neka vrsta troška pa je za očekivati da će ekonomski subjekti taj trošak nastojati minimizirati. U slučaju banaka u sjeni, to se primarno postiže poslovanjem izvan regulatornog okvira čime očekivano dolazi do preuzimanja većih rizika nego što je to slučaj u reguliranom sektoru pa je sukladno tome i očekivani profit veći. Pritom činjenica da dio institucija nije (jednako) reguliran nije nužno loša. Primjerice, moguće je i da zbog ograničenja u poslovanju reguliranih subjekata ili kompleksne regulative (primjerice banaka) dio klijenata ostane nepokriven uslugama tih posrednika. Banke u sjeni u tom slučaju zadovoljavaju potrebe takvih tržišnih sudionika.

Uz to banke u sjeni ne moraju nužno dolaziti potpuno izvan reguliranog sektora. U praksi se opisani poslovni model često provodi preko nekog reguliranog subjekta koji je podvrgnut nižoj, odnosno drugačijoj razini ili vrsti regulacije.

Banke u sjeni pružaju dodatne mogućnosti za financiranje, alternativa su ulaganju u bankovne depozite, efikasnije usmjeravaju sredstva zbog većeg stupnja specijalizacije i omogućuju diversifikaciju rizika smanjivanjem izloženosti bankarskom sektoru (Europska komisija, 2012).

Gledano analitički i poopćeno, aktivna strana bilance banaka u sjeni u pravilu se sastoji od potraživanja koja imaju određenu razinu kreditnog rizika i ročnost, dok su u pasivi obveze prema financijskim institucijama. Za razliku od banaka, gdje regulativa zahtijeva relativno visoku razinu diversifikacije i kontrole kreditnog rizika u aktivi, kod banaka u sjeni takva regulativa izostaje, manja je ili se oslanja na procjenu institucije (tzv. prudent person principle). Slična je stvar i s pasivom. U bankarskom poslovanju regulativa je usmjerena na mogućnost pravovremene isplate depozitara, što podrazumijeva i (dostatnu) likvidnost imovine iz koje bi se mogli namiriti očekivani ili eventualni odljevi. 
Kao najvažniji rizici poslovanja ovakvih subjekata, uz već spomenuti kreditni rizik, ističu se rizici vezani uz ročnu neusklađenost imovine i obveza, rizici vezani uz veliku financijsku polugu te rizik likvidnosti. Osim navedenih rizika koji se tiču banaka u sjeni kao pojedinačnih poduzetnika, ponašanje ovakvih subjekata može dovesti i do sistemskih rizika koji mogu ugroziti financijsku stabilnost. Izloženost više subjekata jednoj vrsti rizika (primjerice tržištu nekretnina ili ulaganjima u dugove kompanija čije je poslovanje u značajnoj mjeri korelirano) uz visoke razine financijske poluge može ugroziti stabilnost financijskog sustava i poticati stvaranje cjenovnih balona s dugoročno negativnim posljedicama. Naravno, preduvjet za ovakve sistemske efekte je da su banke u sjeni kao agregat dovoljno velike, odnosno da je izloženost drugih financijskih institucija prema njima značajna. S obzirom na to da banke u sjeni nisu izolirane od ostatka financijskog sustava, problemi se iz njih preko financijskih tržišta i drugih sudionika procesa financijskog posredovanja vrlo brzo mogu proširiti i na ostale financijske institucije, posebice na banke, a može doći i do prekograničnog prelijevanja nestabilnosti.

No, nedostatak pouzdanih podataka i informacija o poslovanju tih institucija u praksi bitno otežava sagledavanje sistemskih rizika koji bi mogli ugroziti financijsku stabilnost (Adrian, Ashcraft i Cetorelli, 2013).

\section{Bankarstvo u sjeni u Hrvatskoj}

Analitičke podatke o poslovanju banaka u sjeni relativno je teško pronaći, pogotovo one koji bi bili međunarodno usporedivi. Ipak, korištenjem agregatnih podataka o strukturi financijskog sustava na osnovi financijskih računa moguće je indirektno zaključiti koji su dijelovi financijskog sustava potencijalni izvor financiranja u sjeni. Daljnjom analizom takvih segmenata na sektorskoj razini moguće je steći osnovni uvid u preuzete rizike takvih posrednika. Uz usporedbu sa strukturom financijskog sustava u EU-u, fokus je na detaljnoj analizi sektora u Hrvatskoj koji bi mogli biti potencijalno skrovište za banke u sjeni. 
Slijedeći metodologiju Odbora za financijsku stabilnost(Jackson i Matilainen, 2012), osnovni koraci u analizi banaka u sjeni su ocjena njihova udjela u ukupnom financijskom sustavu i makromapiranje financijskog sustava na temelju bilanci financijskih institucija koje omogućuje sagledavanje kretanja u financijskom sustavu tijekom vremena te analizu međusobnih veza institucija unutar sustava. Slijedeći pristupe drugih zemalja, polazna osnova za analizu su financijski računi koji su kompilirani prikaz dostupnih podataka HNB-a, Ministarstva financija, Fine i Hanfe.

Istraživanje potencijalnih rizika vezanih uz bankarstvo u sjeni zasnovano je na analizi strukture i međusobnih veza među dijelovima financijskog sustava te rizika povezanih s ročnim i likvidnosnim (ne)usklađenostima i stupnjem korištenja financijske poluge.

\subsection{Segmenti domaćeg financijskog sustava i usporedba s EU-om}

Podaci o veličini aktive financijskih institucija u Hrvatskoj pokazuju da je segment nebankovnih financijskih institucija i nadalje znatno manji u odnosu na bankarski sektor, čiji udio u ukupnom financijskom sustavu kontinuirano premašuje 70 posto $^{2}$, što Hrvatsku svrstava u bankocentrične sustave karakteristične za većinu europskih zemalja (tablice 2 i 3).

Analiza usporedivih podataka ukazuje na to da je udio banaka u domaćem financijskom sustavu znatno viši u odnosu na prosjek EU zemalja. Isti je slučaj i s mirovinskim fondovima i osiguravajućim društvima, dok ostali financijski posrednici (u biti faktoring društva i društva za lizing) i investicijski fondovi imaju znatno veću relativnu važnost u EU-u nego u Hrvatskoj (slika 1). Istodobno možemo zaključiti da je bankarstvo u sjeni u Hrvatskoj vjerojatno manje prisutno nego u EU-u.

Imajući u vidu strukturu financijskog sustava u Hrvatskoj, "bankarenje u sjeni" moglo bi se očekivati u sektorima osiguranja, ostalih financijskih posrednika i investicijskih fondova. Novčani i mirovinski fondovi nisu

${ }^{2}$ Usporedivi financijski računi dostupni su za razdoblje od 2012. godine (tablice 2 i 3), a za prijašnje razdoblje koriste se dostupni podaci Hanfe i HNB-a (tablica 1).

Privredna kretanja i ekonomska politika | god. 27 | br. 2(143) | 2019. 
posrednici kod kojih je takvo djelovanje jednostavno provedivo zbog razmjerno stroge regulative, odnosno ograničenja ulaganja. Kod novčanih fondova ovakva je mogućnost dodatno ograničena provedbom uredbe o novčanim fondovima koja posebno strogo regulira njihova ulaganja (Uredba 2017/1131 Europskog parlamenta i Vijeća o novčanim fondovima ${ }^{3}$ ).

Za razliku od toga, u sektorima osiguranja, ostalih financijskih posrednika i investicijskih fondova realnije je očekivati ponašanje slično bankama gdje bi ovi posrednici sredstva klijenata ili sredstva pribavljena na financijskim tržištima pokušali plasirati s ciljem ostvarivanja što većih prinosa.

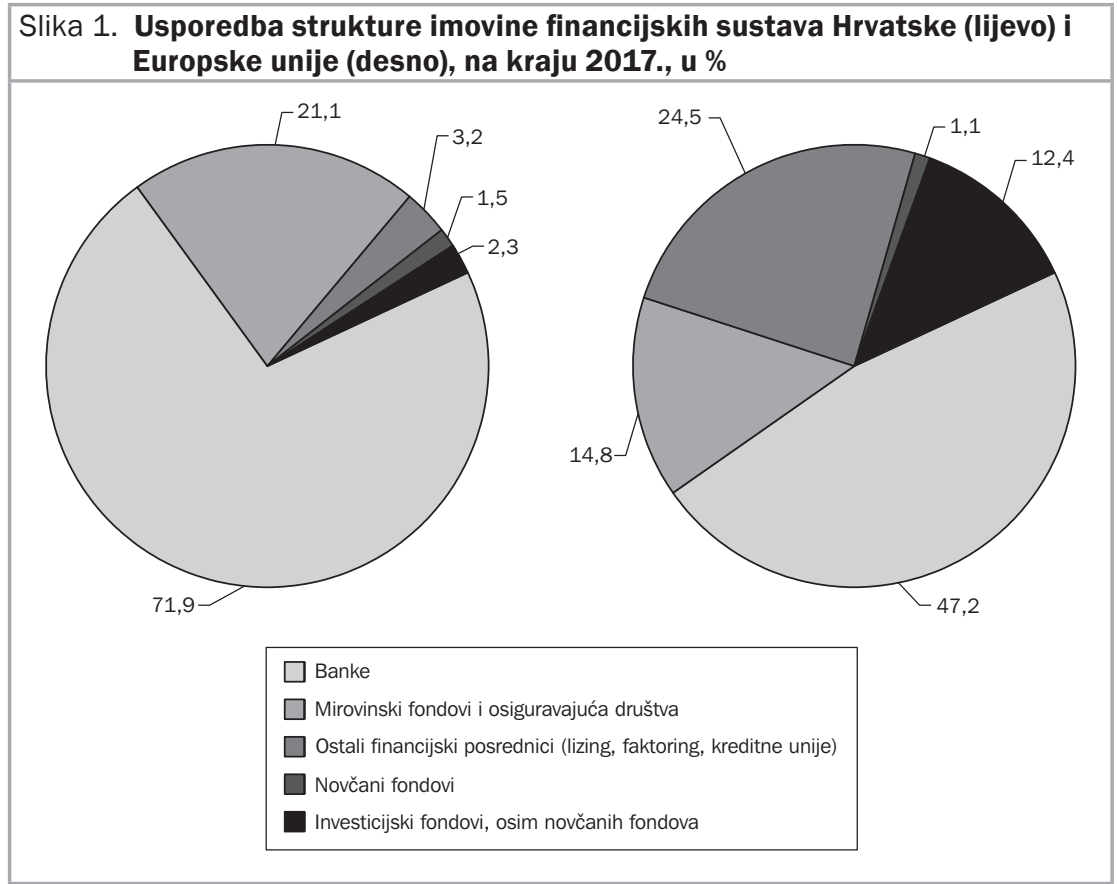

Izvori: HNB - financijski računi, ECB, izračuni autora i izračuni ECB-a.

${ }^{3}$ Detaljnije vidjeti na: https://eur-lex.europa.eu/legal-content/HR/TXT/HTML/suri=CELEX:3 2017R1131\&from $=E N$. 


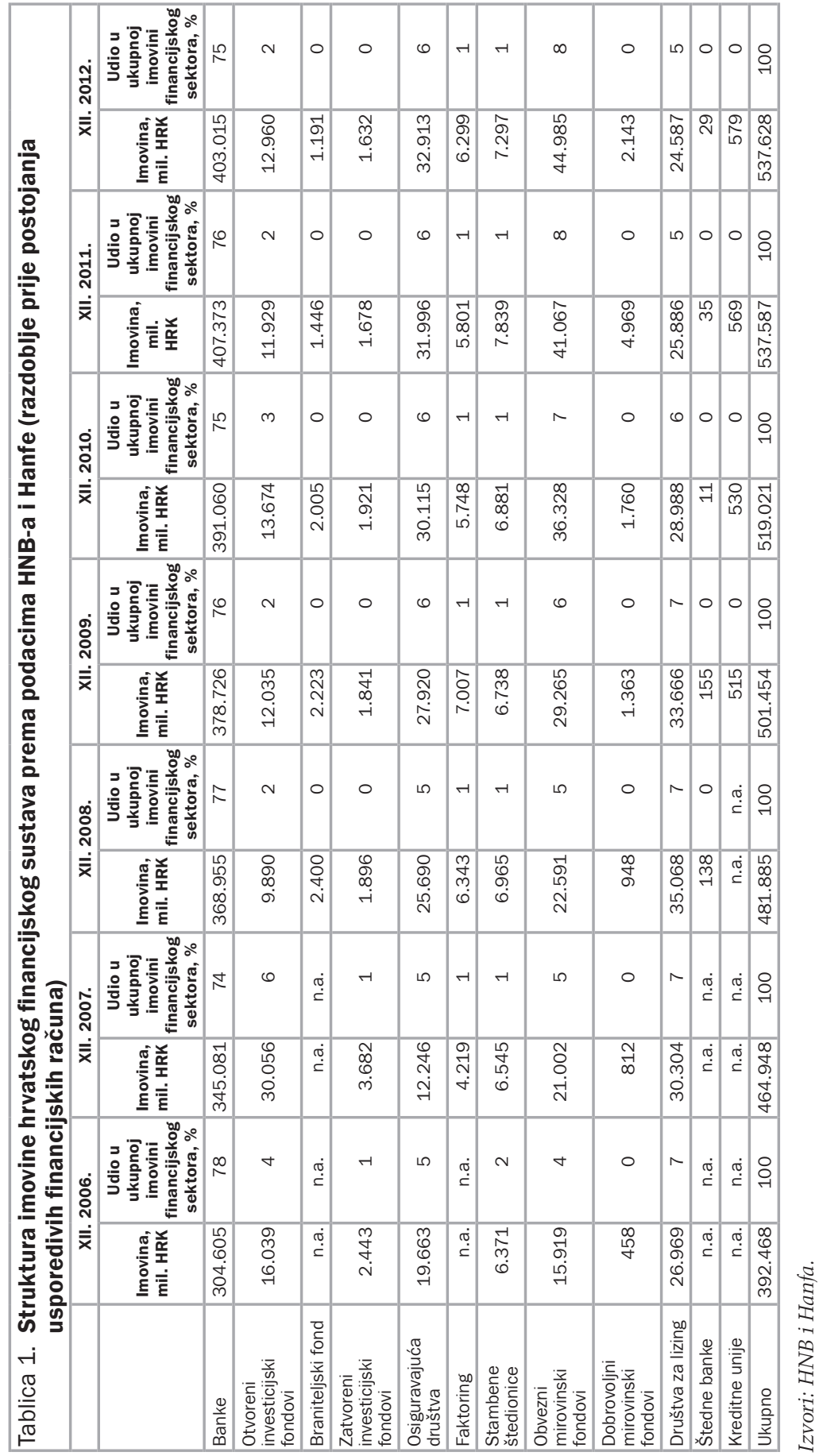

Privredna kretanja i ekonomska politika | god. 27 | br.2(143) | 2019. 


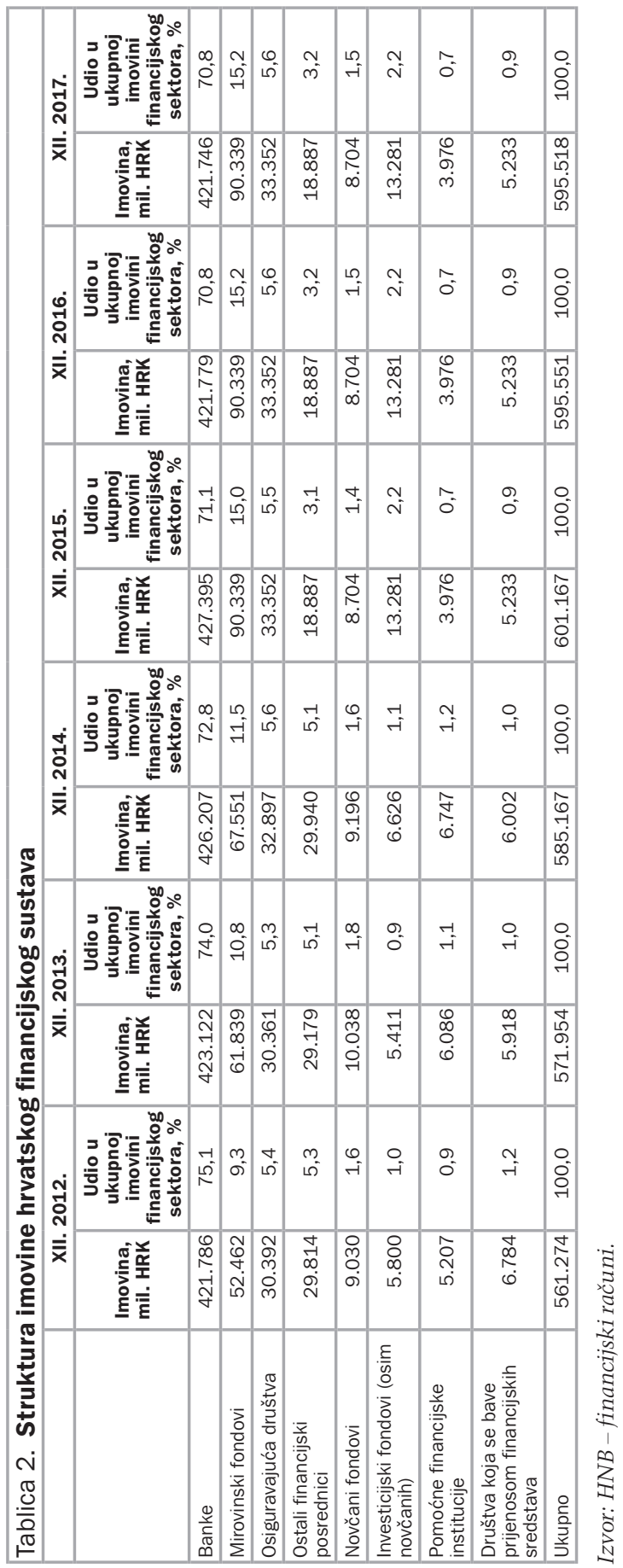




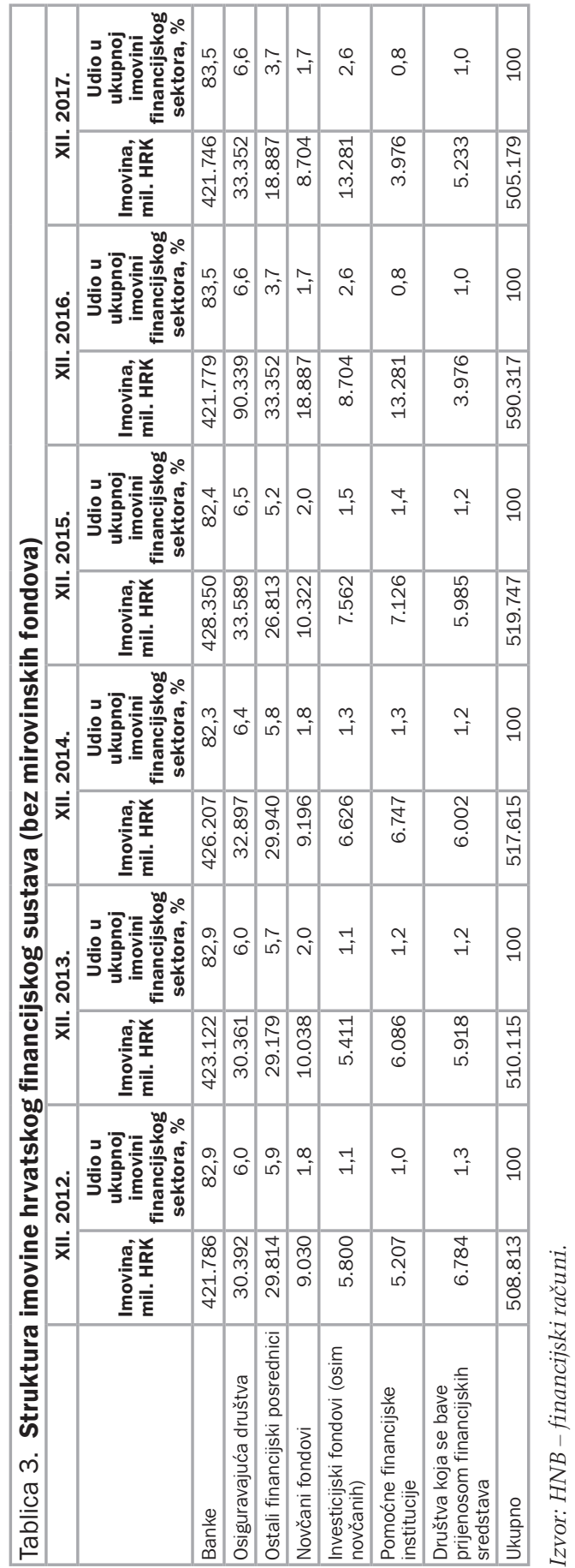

Privredna kretanja i ekonomska politika | god. 27 | br.2(143) | 2019. 
Promatrano tijekom vremena, udio imovine nebankovnih financijskih institucija u ukupnoj imovini financijskog sustava na prvi se pogled postepeno povećavao - s 22 posto na kraju 2006. na oko 29 posto na kraju 2017. (tablice 1 i 2). No, u razdoblju nakon 2008. godine znatno raste udio mirovinskih fondova zbog kontinuiranih uplata članova koje čine glavninu njihove imovine. Stoga, ako se iz financijskih posrednika isključe mirovinski fondovi (tablica 3), može se uočiti da se važnost drugih nebankovnih financijskih posrednika u posljednjih nekoliko godina nije znatnije mijenjala. Usto, treba istaknuti i da je rast imovine dijela nebankovnih financijskih institucija u razdoblju do kraja 2008. u određenoj mjeri bio posljedica regulatorne arbitraže jer su makroprudencijalne mjere u pretkriznom razdoblju bile usmjerene na banke, dok je ostatak sustava bio izvan njihova dosega. Najbolji primjer tog fenomena je kretanje imovine društava za lizing. Usporedbe radi, prema podacima Europskog odbora za sistemske rizike (ESRB) za kraj 2017., prema široj definiciji imovina banaka u sjeni koja uključuje ostale financijske posrednike, investicijske fondove (i novčane i ostale) te društva koja se bave prijenosom financijskih sredstava (društva koja služe za specijalne poslove financiranja, najčešće unutar grupa) iznosila je 42 bilijuna eura, a njihov udio u ukupnoj imovini financijskog sektora EU-a bio je 40 posto (ESRB, 2018).

Uz sektore prikazane u tablicama 1 i 2, treba spomenuti da na domaćem tržištu posluju i kreditni posrednici koji posreduju između davatelja (banke) i primatelja (građana) financijskih usluga na način da pružaju informacije o vrstama i troškovima različitih bankovnih usluga te izravno obavljaju dio poslova s bankom umjesto klijenata. Imatelji odobrenja Ministarstva financija za pružanje usluga potrošačkog kreditiranja ${ }^{4}$ u većini slučajeva imaju ugovore s bankama čije kredite nude po pojednostavljenoj proceduri. Pritom ne naplaćuju uslugu direktno od korisnika, već imaju posebne aranžmane s bankama od kojih ostvaruju prihode.

${ }^{4}$ Detaljnije vidjeti na: http://www.mfin.hr/hr/imatelji-odobrenja-ministarstva-financija-zapruzanje-usluga-potrosackog-kreditiranja. 
Također, ulaskom Hrvatske u EU olakšan pristup domaćem tržištu dobili su subjekti koji pružaju financijske usluge registrirani u zemljama članicama. Dio njihovih aktivnosti evidentiran je izravno u dijelu financijskih računa koji se odnosi na poslovanje s inozemstvom, a dio neizravno preko veza s dijelovima domaćeg financijskog sustava. Iako zasigurno postoji i dio subjekata čije su aktivnosti trenutno izvan dosega službenih evidencija, anegdotalni dokazi u ovom trenutku ne upućuju na to da bi njihovo poslovanje moglo rezultirati sistemskim rizicima.

U nastavku rada analiziraju se osnovni pokazatelji rizika poslovanja, plasmani, obveze te veze među financijskim posrednicima u Republici Hrvatskoj.

\subsection{Odnos kratkoročnih obveza i kratkoročne imovine i stupanj korištenja poluge po sektorima}

Ročna neusklađenost imovine i obveza kod nebankovnih financijskih institucija mjerena omjerom kratkoročnih obveza i kratkoročne imovine ne predstavlja sistemski rizik jer je kod većine sektora taj omjer niži od 100 posto (slika 2). Iznimka su investicijski fondovi, što je očekivano jer se ulozi investitora tretiraju kao kratkoročne obveze, dok se ulaganja u dužničke i vlasničke vrijednosne papire promatraju kao dugoročna imovina, premda karakter tih ulaganja primarno ovisi o likvidnosti tih instrumenata. Korištenje duga u financiranju aktivnosti u većini sektora je nisko što je vidljivo po omjeru obveza i kapitala, uz iznimku ostalih financijskih posrednika (faktoring društva i društva za lizing), što upućuje na potencijalne rizike u njihovu poslovanju (slika 2). 


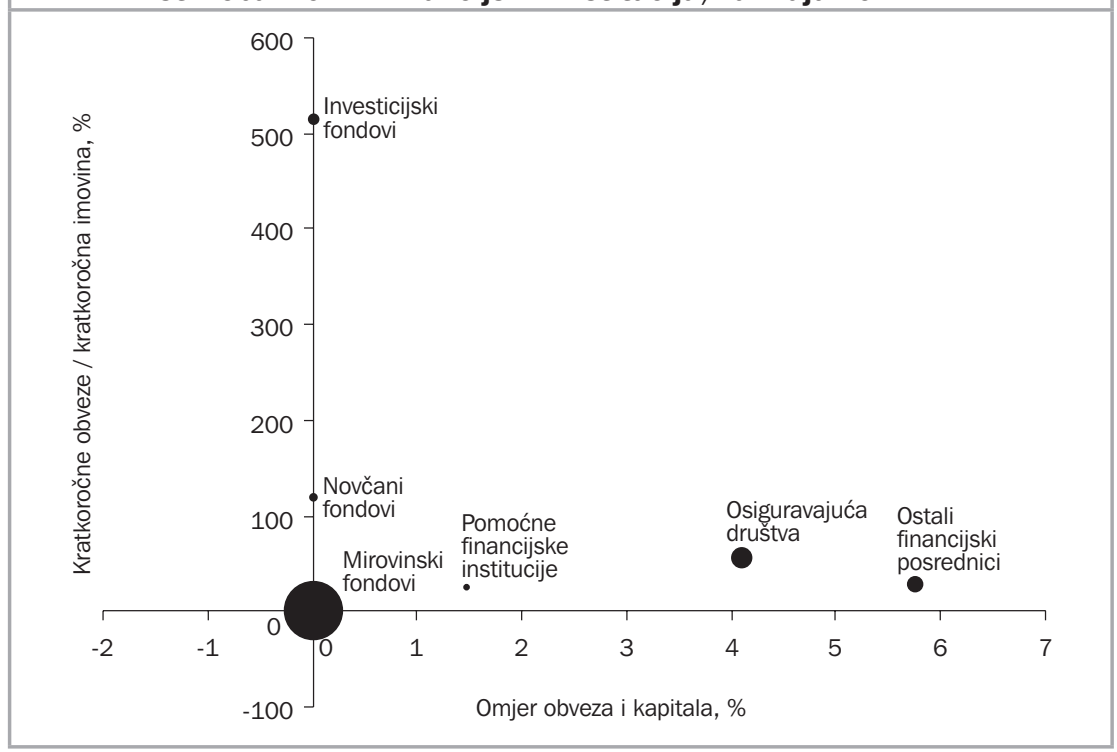

Napomena: Veličina kruga odražava relativnu veličinu pojedine grupe financijskih institucija. Izvor: HNB - financijski računi.

\subsection{Međusobne izloženosti financijskih institucija i odabranih sektora}

Kako bi se stekao opći dojam o međusobnim vezama financijskih institucija, one su osim putem grafikona i tablica prikazane i pomoću mrežnih prikaza koji sadržavaju podatke o relativnoj veličini pojedinih nebankovnih financijskih institucija, njihovu stupnju korištenja poluge i međusobnim izloženostima te potraživanjima i obvezama prema državi, inozemstvu, poduzećima i stanovništvu koje premašuju određeni udio u aktivi svakog pojedinog sektora (slika 3). Mrežna analiza među sektorima u tom kontekstu upućuje na važan položaj države, banaka i nefinancijskih poduzeća prema kojima pojedini sektori imaju visoke izloženosti u odnosu na njihovu ukupnu imovinu (slika 3a). 


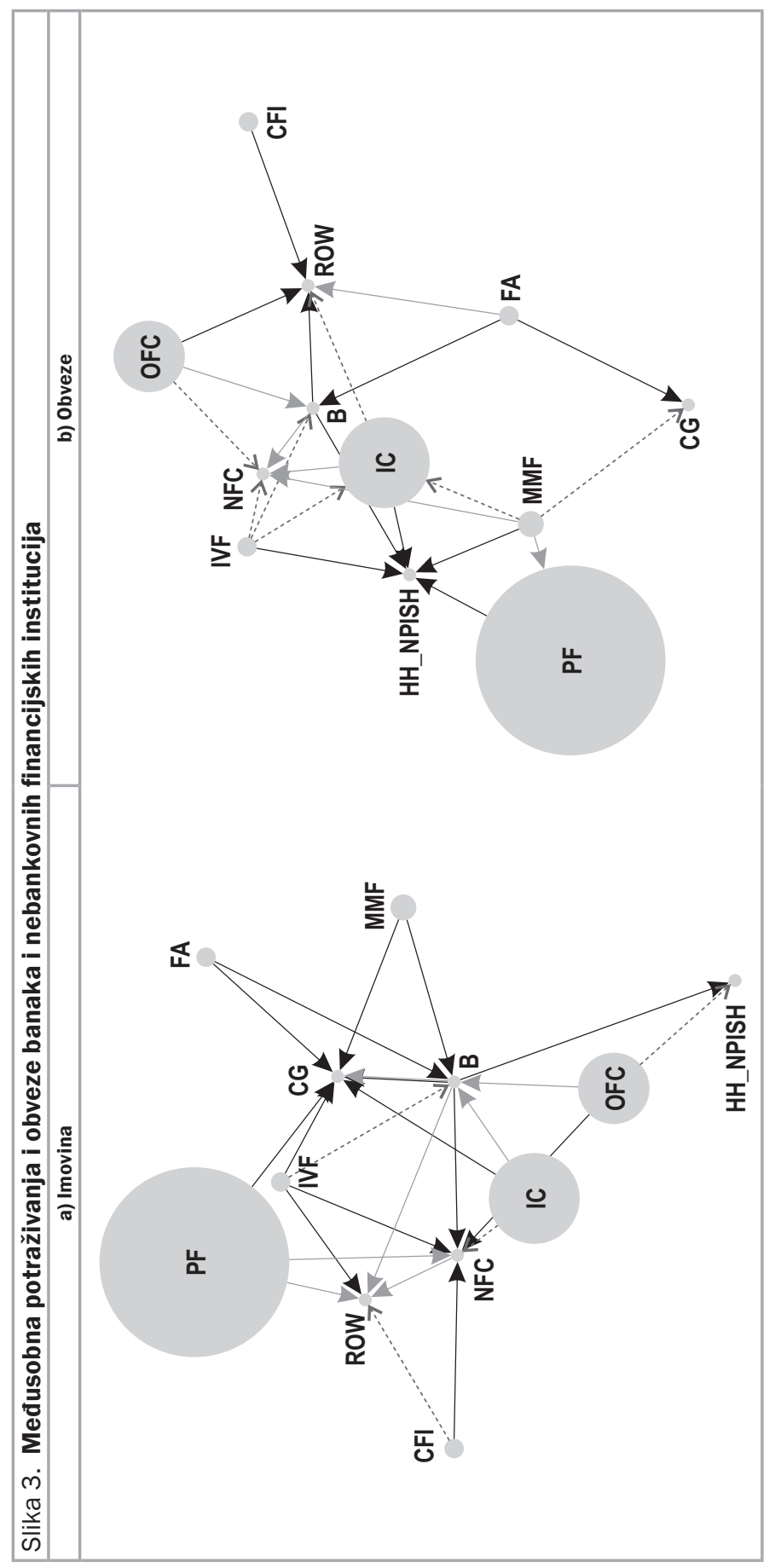

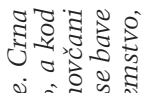

$\because \div \circ \approx$ क ह

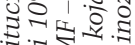

吾记

잔

건젼

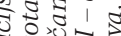

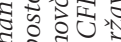

z. $z$ :

a $\pi \cdot \overline{2} \cdot 3 \cdot \frac{7}{3}$

.

$\square=8.75$

ฐา. ㄷำ

궁

녕: :

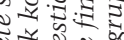

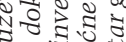

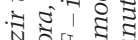

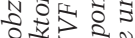

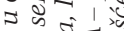

₹ $05 \mathbb{2}$

격종ำ

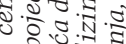

5. $2 \cdot \frac{2}{2} \cdot \frac{3}{3}$

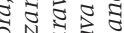

200,

2. 0.507

원ㄷำ

농

응 है논

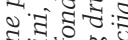

5. 5.7

I. .

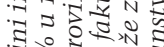

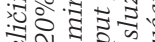

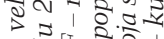

.5.

ส 2 .

ป ป च

일

. 00.8

5.

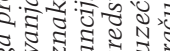

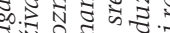

공.

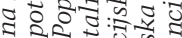

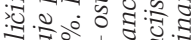

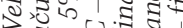

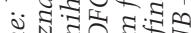

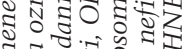

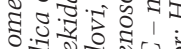

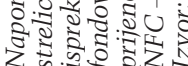

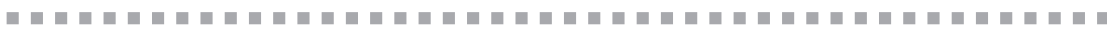

Privredna kretanja i ekonomska politika | god. 27 | br. 2(143) | 2019. 
Slika 3 prikazuje piktograme koji na sumaran način pokazuju veze između nebankovnih financijskih institucija, strukturu njihove imovine (slika 3a) i strukturu njihovih obveza (slika 3b). Različite strelice u piktogramima pokazuju različite razine izloženosti tako da isprekidane strelice pokazuju izloženosti od 5 do 10 posto, sive od 10 do 20 posto, a crne više od 20 posto udjela u imovini (slika 3a) i obvezama (slika 3b). Veličina krugova (samo za nebankovne financijske institucije) pokazuje veličinu imovine odnosno obveza.

Slika 3 jasno pokazuje dominaciju mirovinskih fondova u ukupnoj imovini nebankovnih financijskih posrednika. Mirovinske fondove po imovini slijede osiguranja, te lizing i faktoring društva.

U smislu izloženosti kroz ulaganje imovine, vidljiva je dominantna uloga središnje države, nefinancijskih poduzeća i banaka. Što se tiče izvora sredstava (obveza) dominantna je uloga sektora kućanstava, inozemstva, ali i banaka.

\subsection{Međusobne izloženosti nebankovnih financijskih institucija i banaka}

Zbog međusobne povezanosti financijskih institucija i mogućnosti prelijevanja problema iz jednog dijela financijskog sustava u druge dijelove ovdje se sagledavaju međusobne izloženosti nebankovnih financijskih institucija prema bankama, odnosno banaka prema nebankovnim financijskim institucijama, s posebnim naglaskom na ročnu strukturu tih izloženosti. Usto, prikazana je i matrica svih međusobnih izloženosti pojedinih sektora unutar financijskog sustava u apsolutnim iznosima (tablica 4). 


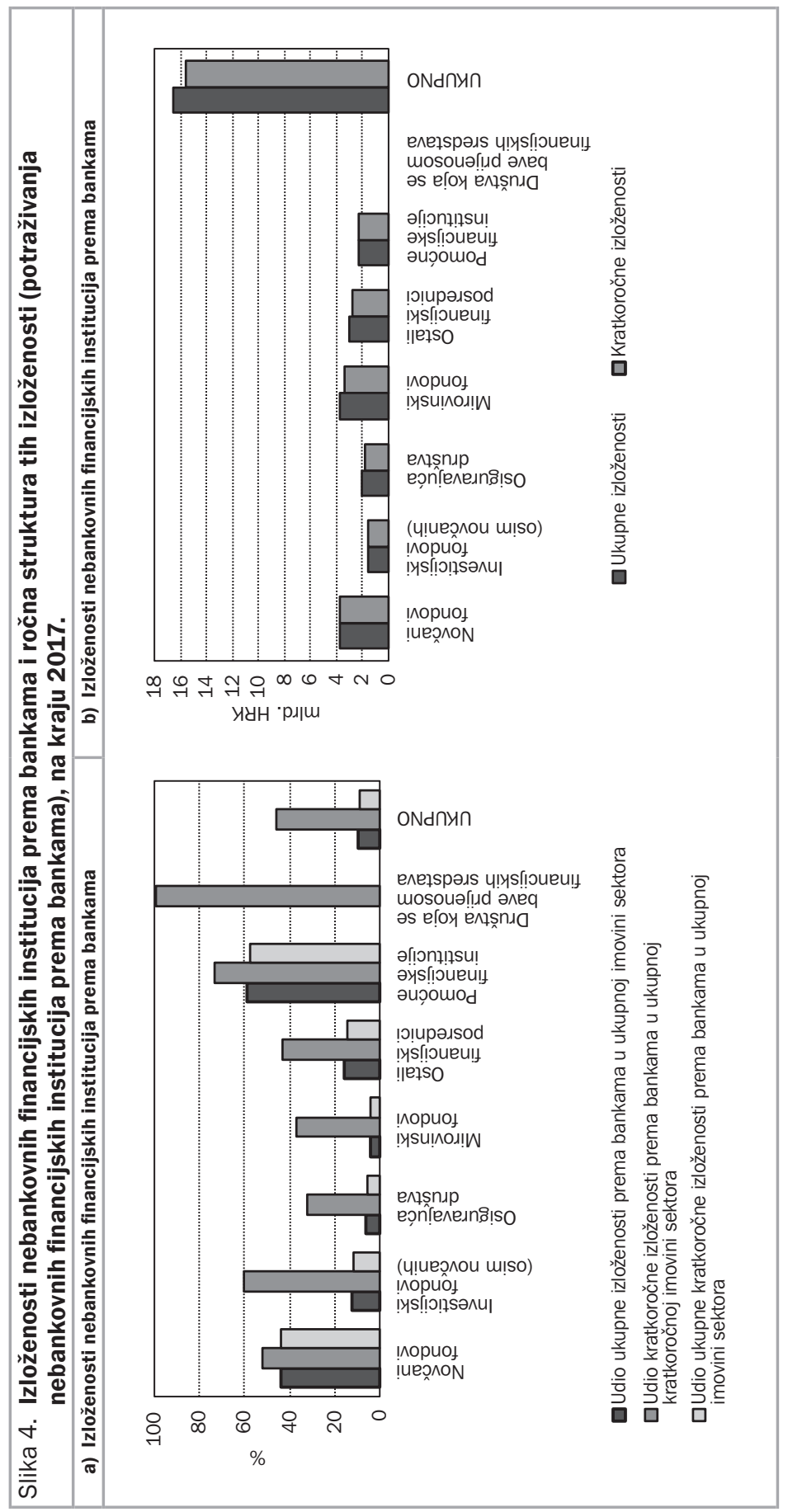

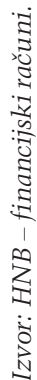

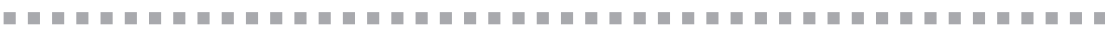

Privredna kretanja i ekonomska politika | god. 27 | br. 2(143) | 2019. 


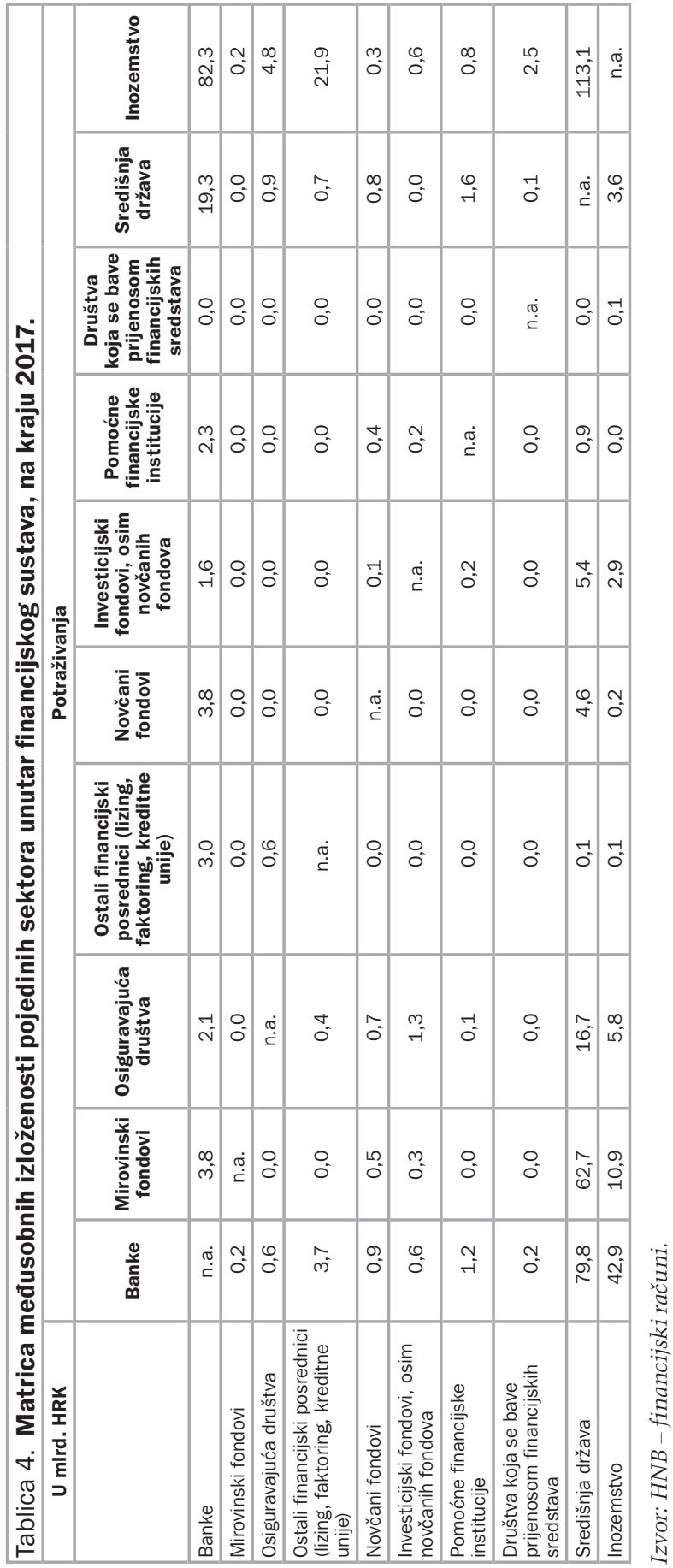


Relativno visoka kratkoročna izloženost dijela nebankovnih financijskih institucija prema bankama upućuje na potencijalni rizik prenošenja likvidnosnih šokova iz bankarskog sektora prema tim institucijama. Kratkoročna izloženost većine nebankovnih financijskih institucija u odnosu na njihovu imovinu relativno je visoka, posebno kod pomoćnih financijskih institucija te investicijskih i novčanih fondova gdje taj udio premašuje 50 posto, a ako se promatra ukupna izloženost prema bankama u odnosu na imovinu pojedinog sektora ona je najveća kod pomoćnih financijskih institucija i novčanih fondova (slika 4).

Kratkoročna izloženost banaka prema nebankovnim financijskim institucijama zanemariva je u odnosu na njihovu ukupnu imovinu i ukupnu imovinu financijskog sektora i ne čini sistemski rizik (slika 5). Pritom su banke ukupno najviše izložene prema ostalim financijskim posrednicima, što iznosi oko 1 posto njihove ukupne aktive (slika 5a).

\subsection{Izloženost nebankovnih financijskih institucija prema državi i oslanjanje na inozemne izvore financiranja}

Uz analizu međusobnih izloženosti financijskih institucija, provedena je i analiza izloženosti nebankovnih financijskih institucija prema sektoru države. S obzirom na visoku razinu javnog duga i rizike povezane s njegovim financiranjem i refinanciranjem, to je ocijenjeno kao potencijalni izvor sistemskih rizika, koji se u slučaju nastupanja vanjskog ili unutarnjeg šoka koji bi otežao otplatu državnog duga mogu preliti na financijski sustav (slika 6). Kratkoročne izloženosti nebankovnih financijskih institucija prema državi u odnosu na imovinu pojedinog sektora najizrazitije su kod novčanih fondova, a najveće dugoročne izloženosti očekivano su zabilježene i kod mirovinskih fondova i osiguravajućih društava (slika 6a). 


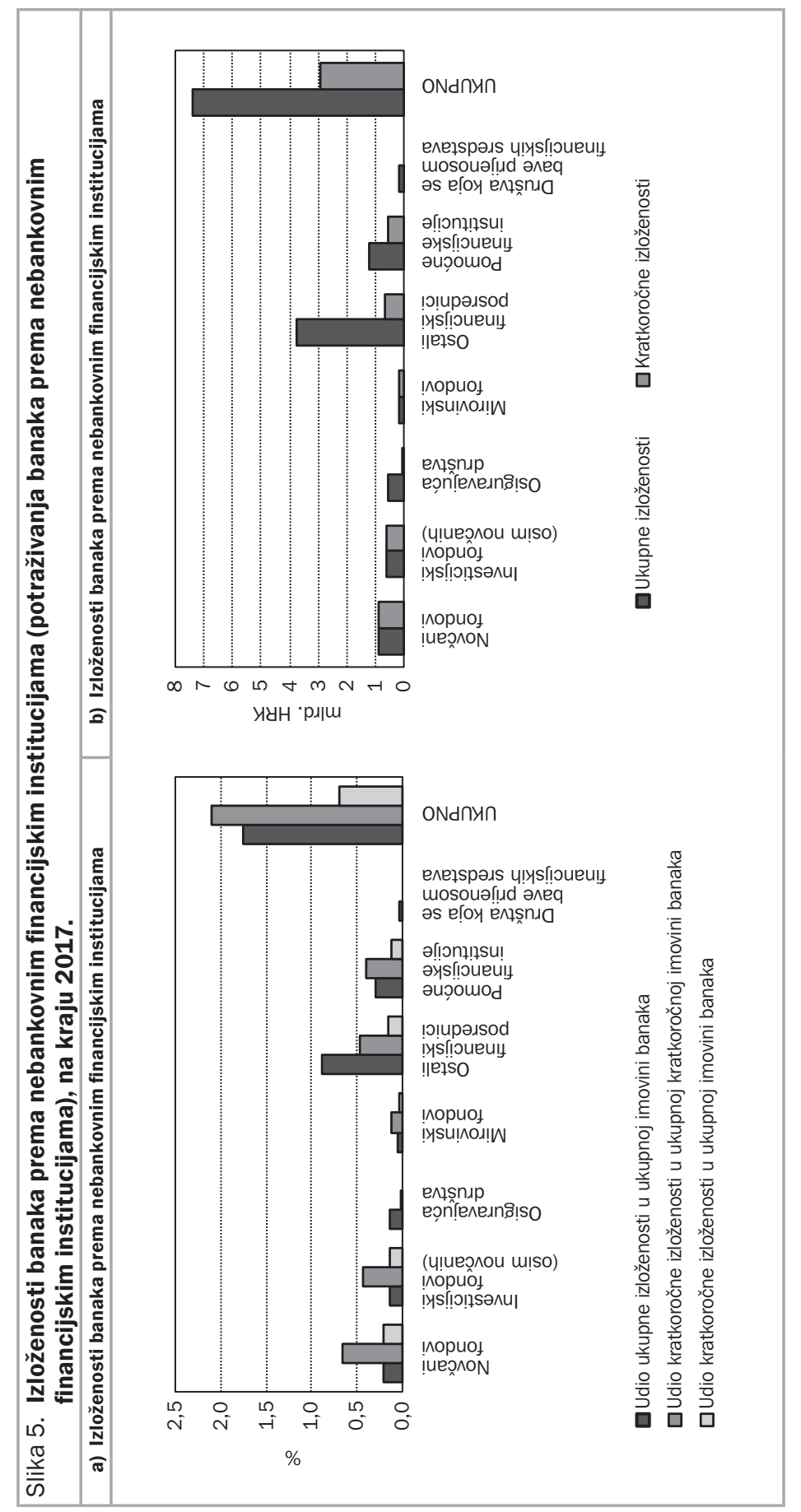

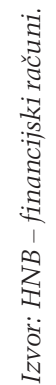




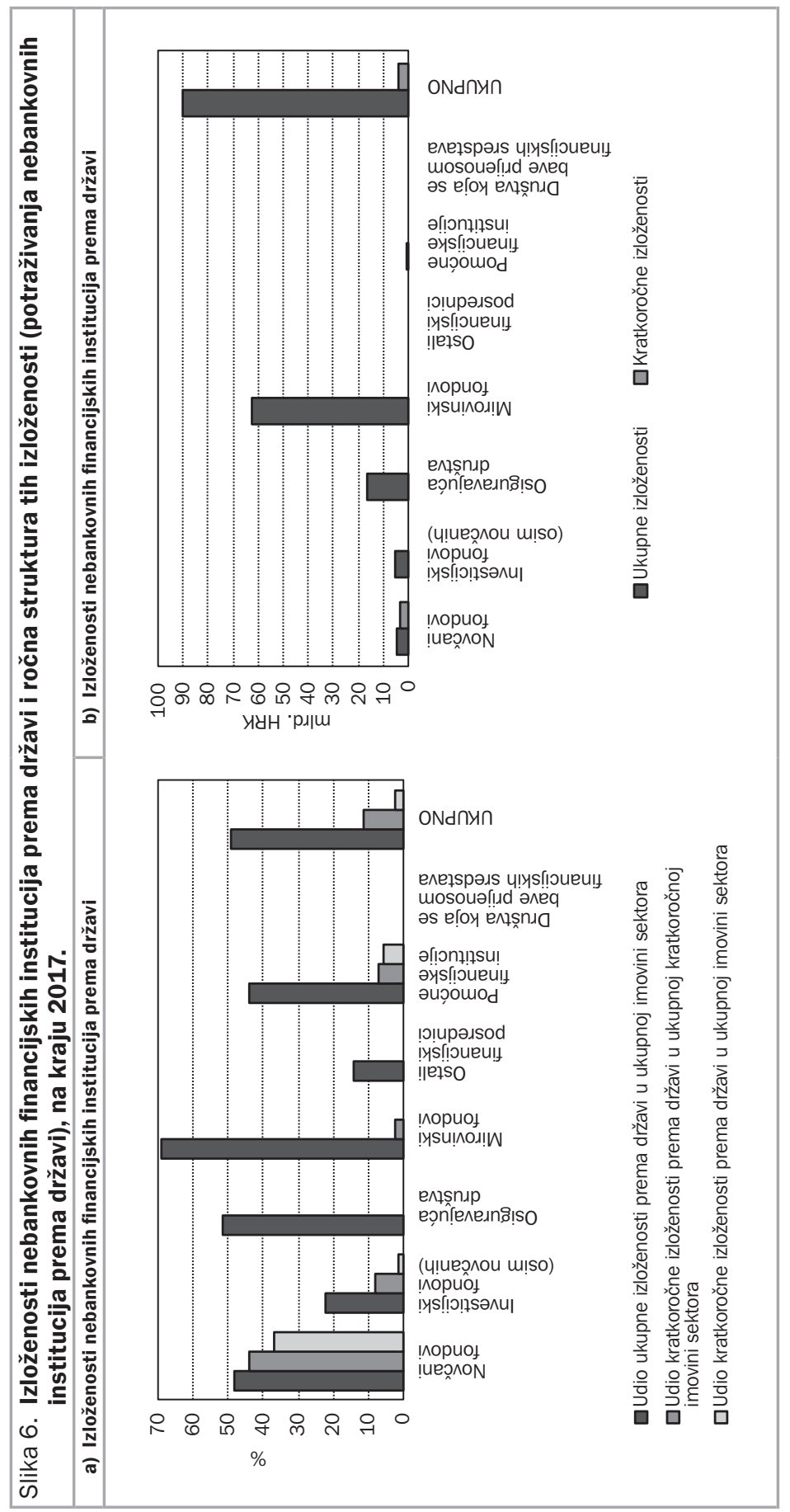

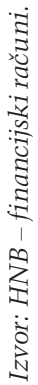

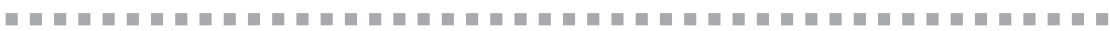

Privredna kretanja i ekonomska politika | god. 27 | br. 2(143) | 2019. 
Relativno snažno oslanjanje dijela nebankovnog financijskog sustava na inozemne izvore financiranja također je ocijenjeno kao potencijalni sistemski rizik jer takvi izvori mogu biti kolebljivi te u slučaju povlačenja mogu rezultirati problemima u tim institucijama, ali i prelijevanjem problema na ostatak financijskog sustava (slike 3a i 7). Ako zbog malog udjela u ukupnom financijskom sustavu zanemarimo društva koja se bave prijenosom financijskih sredstava (društva koja služe za specijalne poslove financiranja, najčešće unutar grupa), najveći stupanj kratkoročne i ukupne izloženosti prema inozemnim izvorima financiranja zabilježen je kod ostalih financijskih posrednika (slika 7). Detaljnija analiza njihovih obveza pokazuje da je primarno riječ o dugoročnim kreditima koji su na kraju 2017. iznosili 18 milijardi kuna i činili 64 posto njihovih ukupnih obveza, odnosno gotovo 84 posto njihovih inozemnih obveza.

\subsection{Regulatorna arbitraža}

Analizirajući domaća iskustva s regulatornom arbitražom mogu se izdvojiti dva najvažnija primjera takvog djelovanja financijskih institucija. Prvi način izbjegavanja regulative središnje banke odvijao se unutar domaćeg financijskog sustava, a drugi putem prekograničnog kreditiranja domaćih subjekata.

Regulatorna arbitraža unutar domaćeg financijskog sustava dogodila se prebacivanjem poslovanja iz strože reguliranog bankarskog sektora u slabije regulirane segmente financijskog sustava, što se odvijalo u razdoblju kada je na snazi bio cijeli niz mjera središnje banke kojima se nastojala usporiti kreditna aktivnost banaka s ciljem ublažavanja rasta vanjskih neravnoteža i usporavanja prebrzog gospodarskog rasta. Tada su klijentima umjesto bankovnih kredita nuđeni ugovori za lizing, čime su se direktno zaobilazile mjere središnje banke. To je rezultiralo relativno visokim stopama rasta imovine ovih financijskih posrednika u razdoblju prije krize (tablica 1). 


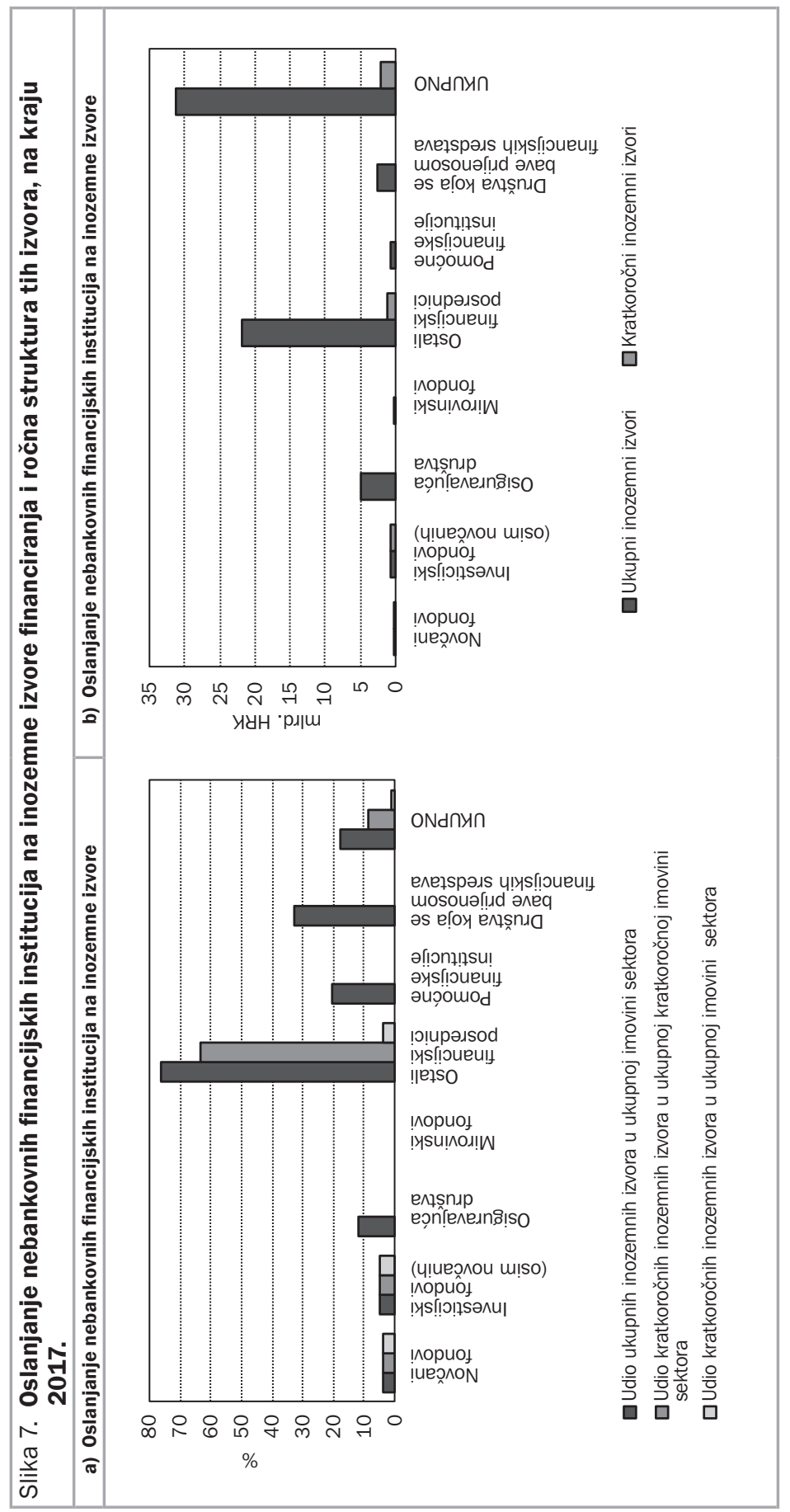

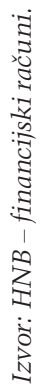

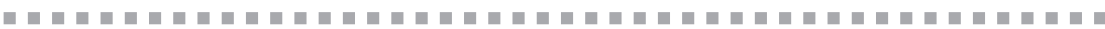

Privredna kretanja i ekonomska politika | god. 27 | br. 2(143) | 2019. 
Drugi oblik regulatorne arbitraže uključivao je strane banke majke domaćih banaka. Iako se prema "udžbeničkoj" definiciji bankarstva u sjeni takvom vrstom djelovanja bave nebankovne financijske institucije, slučaj prebacivanja poslovanja domaćih banaka na banke majke u razdoblju dok su na snazi bile makroprudencijalne mjere središnje banke usmjerene na usporavanje kreditne aktivnosti u suštini odgovara konceptu takve vrste poslovanja. Naime, u tom razdoblju međunarodne bankarske grupacije bile su slabije regulirane u odnosu na domaći bankarski sektor jer za njih nisu vrijedila ograničenja kreditiranja postavljena domaćim bankama, a domaće banke imale su interes za prebacivanje posla u inozemne institucije jer su s njima bile vlasnički povezane. Vlasnička struktura domaćeg bankarskog sektora s više od 90 posto aktive u stranom vlasništvu u kombinaciji s izostankom međunarodne koordinacije u provođenju makroprudencijalne politike pogodovala je pojavi regulatorne arbitraže te smanjila doseg domaće makroprudencijalne politike u ublažavanju sistemskih rizika i pospješila njihovu transmisiju i među državama i među institucijama. Navedeno je vidljivo po bržim stopama rasta inozemne zaduženosti poduzeća putem izravnog inozemnog zaduživanja u razdoblju kada je HNB ograničavao rast plasmana domaćih banaka u periodu od 2003. godine do početka krize ${ }^{5}$ (slika 8).

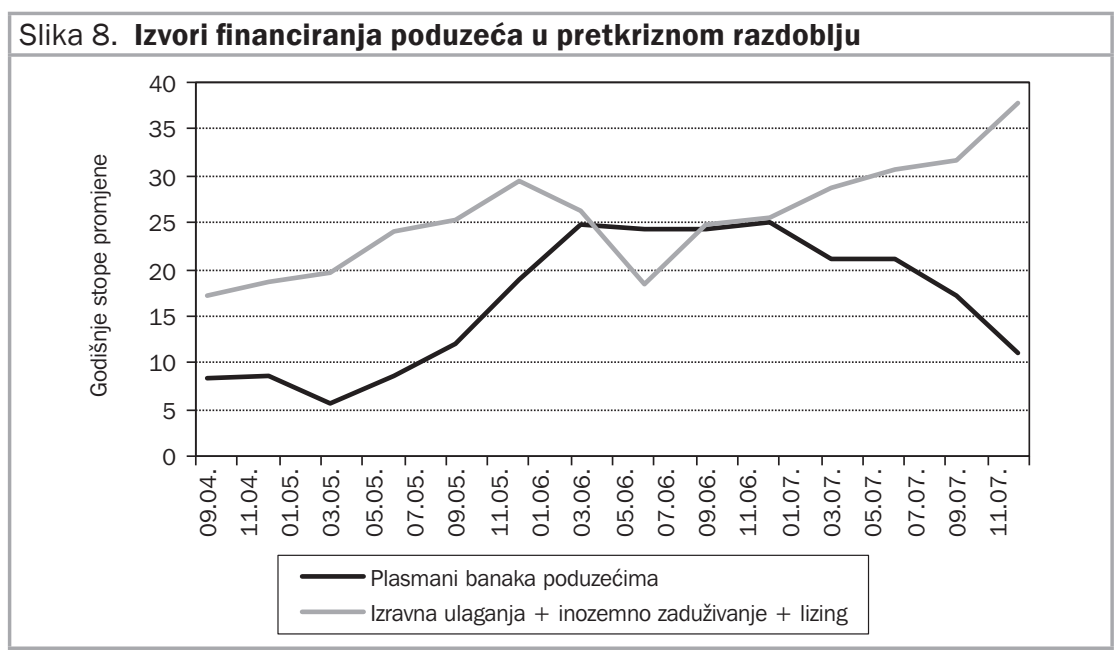

Izvori: HNB i Hanfa.

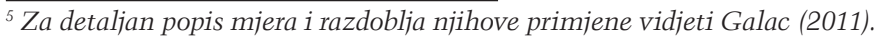


Navedeni primjer dodatno naglašava važnost međunarodne koordinacije u izradi okvira za regulaciju svih financijskih institucija, odnosno koordinacije u provođenju makroprudencijalne politike i na nacionalnoj i na međunarodnoj razini, a ujedno potvrđuje i važnost usklađene međunarodne regulacije banaka i nebankovnog segmenta financijskog sustava.

Svjesna važnosti smanjivanja prostora za regulatornu arbitražu i slijedeći preporuku Europskog odbora za sistemske rizike, Hrvatska je krajem 2013. donijela poseban zakon kojim je osnovano Vijeće za financijsku stabilnost, sastavljeno od predstavnika HNB-a, Hanfe, Ministarstva financija i Državne agencije za sanaciju banaka i osiguranje štednih uloga, a među glavne zadatke Vijeća spadaju oblikovanje makroprudencijalne politike u Hrvatskoj te identifikacija, ocjenjivanje i razmatranje sistemskih rizika i osiguravanje suradnje i razmjene informacija među nadležnim tijelima.

Pitanje međunarodne regulatorne arbitraže u bankarskom poslovanju prepoznato je i na razini EU-a, a zahvaljujući članstvu u EU-u te ograničavanju rasta prekograničnih izloženosti i uvođenju sustava reciprociranja makroprudencijalnih mjera, prostor za takve aktivnosti time je smanjen i za regulirani, ali neizravno i za neregulirani dio financijskog sustava, odnosno banke u sjeni.

\section{Zaključak}

Provedena analiza upućuje na to da visina udjela nebankovnih financijskih institucija u hrvatskom financijskom sustavu te ročna struktura njihovih obveza i potraživanja trenutačno ne predstavljaju rizik koji bi mogao ugroziti stabilnost sustava u cjelini. No, zbog visokog stupnja kratkoročnih izloženosti nebankovnih financijskih institucija prema bankama, izraženi su rizici prelijevanja mogućih šokova iz bankovnog sektora na te institucije. Dio tih institucija uvelike se oslanja i na inozemne izvore financiranja, što može rezultirati problemima u slučaju turbulencija na međunarodnim financijskim tržištima. Promatrano po segmentima nebankovnog dijela financijskog sustava, među najrizičnijim institucijama izdvaja se grupa 
ostalih financijskih posrednika gdje dominiraju faktoring društva i društva za lizing kod kojih su zabilježeni visok stupanj korištenja financijske poluge te znatna kratkoročna i ukupna izloženost prema inozemnim izvorima financiranja.

S ekonomskog stajališta, provedeno istraživanje ukazuje i na koristi i troškove dodatne regulacije nekog sektora. Takozvani normativni optimizam, koji pretpostavlja da će dobra regulacija riješiti sve probleme u nekom području, ovdje vidljivo dolazi u pitanje. Naime, praksa očekivano pokazuje da ekonomski agenti troškove dodatne regulacije pokušavaju minimizirati na razne kreativne načine. Time ne samo da se poništavaju potencijalne koristi regulative, već se, zbog prelaska dijela poslovanja u neregulirani sektor, gube i neke osnovne informacije o poslovnom modelu, kao i eventualni dosezi vezani uz zaštitu potrošača. Uz to, za očekivati je da će troškove regulacije ekonomski agenti pokušati prevaliti na svoje klijente.

Ovaj rad također upućuje na potrebu nastavka analitičkog i istraživačkog rada na polju bankarstva u sjeni. Osim prikaza rizika i veza između različitih vrsta financijskih posrednika, kako je to učinjeno u ovom radu, moguće je provesti analizu i na razini pojedinačnih kompanija i njihovih veza, koje u nekim slučajevima mogu biti izvor rizika za financijsku stabilnost. Naposljetku, posebnu pozornost zahtijeva i analiza rizika povezana s uporabom različitih vrsta izvedenica. 
Adrian, T., Ashcraft, A. B. i Cetorelli, N. (2013). Shadow bank monitoring. Federal Reserve Bank of New York Staff Report No. 638. doi: https://doi. org/10.2139/ssrn.2334918

Economist. (2014, May 10). Shadow and substance [Special report: International banking].

Europska komisija. (2012). Green paper on shadow banking. Bruxelles: Europska komisija.

Europska komisija. (2013). Communication on shadow banking: Frequently asked questions [Memo]. Bruxelles: Europska komisija.

Europska komisija. (2018). What is the capital markets union? Dostupno na: https://ec.europa.eu/info/business-economy-euro/growth-and-investment/ capital-markets-union/what-capital-markets-union_en

Europski odbor za sistemske rizike (ESRB). (2018). EU shadow banking monitor No. 3. Frankfurt: Europski odbor za sistemske rizike.

Galac, T. (2011). Središnja banka kao krizni menadžer u Hrvatskoj analiza hipotetičnih scenarija. Istraživanja HNB-a br. 34. Zagreb: Hrvatska narodna banka.

Jackson, C. i Matilainen, J. (2012, kolovoz). Macro-mapping the euro area shadow banking system with financial sector balance sheet statistics. Rad predstavljen na konferenciji IFC Conference on Statistical Issues and Activities in a Changing Environment, Basel.

Kodres, L. E. (2013, lipanj). What is shadow banking? Finance and Development, 50(2), 42-43. 


\title{
Abstract \\ Are Shadow Banks Hiding in Croatia as Well?
}

\author{
RESEARCH ARTICLE \\ Mirna Dumičić \\ Tomislav Ridzak ${ }^{* *}$
}

This paper aims to shed light on the term shadow banking and the importance of examining shadow banks and their activities from the point of view of financial stability. In this context, an analysis of the domestic financial system and business practices was made in order to assess the role of shadow banks in Croatia and identify systemic risks that may arise from that source. The results of the analysis suggest that the share of non-bank financial institutions and the maturity structure of their liabilities and assets do not currently pose a risk that could threaten financial stability, while the group of other financial intermediaries, including leasing, factoring and credit unions, stands out among the most risky institutions.

Keywords: shadow banks, banking sector, non-bank financial institutions, macroprudential policy, financial stability, systemic risks, Croatia

JEL classification: E51, F34, G01, G21, G23

\footnotetext{
* Mirna Dumičić, Croatian National Bank, e-mail: mdumicic@gmail.com.

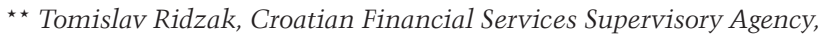
e-mail: tomislav.ridzak@hanfa.hr.
} 